\title{
Disentangling Challenges to Scaling Alternate Wetting and Drying Technology for Rice Cultivation: Distilling Lessons From 20 Years of Experience in the Philippines
}

\author{
Yuji Enriquez ${ }^{1 *}$, Sudhir Yadav ${ }^{2 *}$, Gio Karlo Evangelista ${ }^{2}$, Donald Villanueva ${ }^{1}$, \\ Mary Ann Burac ${ }^{2}$ and Valerien Pede ${ }^{1}$
}

${ }^{1}$ Impact Evaluation, Policy and Foresight Unit, International Rice Research Institute, Los Baños, Philippines, ${ }^{2}$ Soil, Water and Environment Unit, Sustainable Impact Platform, International Rice Research Institute, Los Baños, Philippines

OPEN ACCESS

Edited by:

Ilona M. Otto,

Potsdam Institute for Climate Impact

Research (PIK), Germany

Reviewed by:

lan Charles Dodd,

Lancaster University, United Kingdom

Jorge A. Zegbe,

Instituto Nacional de Investigación Forestal, Agropecuaria

(INIFAP), Mexico

${ }^{*}$ Correspondence:

Yuji Enriquez

y.enriquez@irri.org

Sudhir Yadav

s.yadav@irri.org

Specialty section:

This article was submitted to

Water-Smart Food Production,

a section of the journal

Frontiers in Sustainable Food Systems

Received: 04 March 2021

Accepted: 17 May 2021

Published: 21 June 2021

Citation:

Enriquez Y, Yadav S, Evangelista GK, Villanueva $D$, Burac MA and Pede V (2021) Disentangling Challenges to Scaling Alternate Wetting and Drying Technology for Rice Cultivation: Distilling Lessons From 20 Years of Experience in the Philippines. Front. Sustain. Food Syst. 5:675818. doi: 10.3389/fsufs.2021.675818
Alternate wetting and drying (AWD) is a low-cost innovation that enables farmers to adapt to increasingly water scarcity conditions (such as drought), increase overall farm production efficiency, and mitigate greenhouse gas (GHG) emissions. It is seen as a pathway for transforming agri-food systems into more resilient, productive, biologically diverse, and equitable forms, ensuring our commitments to the UN Sustainable Development Goals (SDGs). This paper uses scaling up and innovation uncertainty frameworks to review the success and challenges of AWD's 20-year scaling trajectory in the Philippines and explain the key factors that have influenced its outcomes. The framework adapted for this study is also used to examine the fitness between the scaling context and requirements, organizational mission, and corresponding capabilities. Findings show the innovation platform that vertically integrated key actors and locally adapted AWD has helped foster essential breakthroughs in creating an enabling environment that took AWD to national policy adoption in the Philippines. However, the dominant focus on technology transfer, product focus, and preference for controlled environments in the scaling practice has neglected many important contextual factors, allowing mismatches in enabling policy incentives, institutions, and scale to diminish the impacts of AWD in gravity-based systems. Our findings suggest that rethinking and re-envisioning the ways in which the impact can be scaled in irrigation rice systems using AWD is critical to sustaining food security and making the agriculture sector more resilient to climate change.

Keywords: scaling strategies, diffusion of innovations, impact, climate mitigation and adaptation, innovation systems, water management, system resilience

\section{INTRODUCTION}

In any rice-based developing economy, irrigation is a precondition for boosting agricultural production. But rising population, competing water uses among various sectors, and worsening climate conditions make it challenging for farmers to have sufficient water at the right place and at the right time. Agriculture uses $\sim 70 \%$ of the planet's freshwater supply (Campbell et al., 2017), of 
which $40 \%$ is used for rice cultivation. As a staple food for half of humanity, more than 3 billion people rely on this crop as their main source of livelihood. Therefore, enhancing rice production-and looking for ways to cultivate it with less water-is essential to assuring global food security. With current practices, rice production not only consume vast amounts of water; it also releases a significant amount of greenhouse gas $(\mathrm{GHG})$ into the atmosphere. An estimated $10 \%$ of global agricultural methane emissions are generated by rice production, and its cultivation is second only to livestock production as a source of methane emissions (Tubiello et al., 2014). While globally, rice production contributes only $1.5 \%$ of the total anthropogenic GHG, this share is much higher in rice-producing countries (Wassmann et al., 2019).

The Philippine agricultural sector is intricately linked to farm employment and the economy, water use, and GHG emissions. Agriculture is an essential pillar of the economy and is a significant water user in the country, accounting for $73 \%$ of the country's total water consumption and secondlargest emitter of GHGs, contributing $53.7 \mathrm{MtCO}_{2} \mathrm{e}$ to the national total emissions (FAO, 2018). Annual per capita water availability in the Philippines has been in constant decline due to increased water demand. This results from economic and population growth and decreased water supply associated with the degradation of watersheds and climate change. In fact, the Philippines was rated the second most at-risk nation in 2018 by the 2020 Global Climate Risk Index and has consistently ranked in the top 20 since 2015 (Eckstein et al., 2020). The IPCC 2018 Special Report projects that a $0.5^{\circ} \mathrm{C}$ increase from the $1.5^{\circ} \mathrm{C}$ warming scenario will likely result in more severe climate change impacts and associated risks on ecosystems through increased temperature extremes and increased frequency and intensity of heavy precipitation and drought (IPCC, 2018). This is why the agriculture sector is a vital aspect of a country's resilience building; it is not only the most vulnerable in terms of the devastating impacts of climate variability and increasing frequency of extreme weather events, it is also an important sector from the standpoint of mitigating climate change. Seventy percent of the area harvested to paddy rice comes from the irrigated ecosystems of the country, which contribute $77 \%$ of the total rice produced (PSA, 2020). Of the total rice area, 3.26 million ha is under the irrigated environment and contributes $77 \%$ of the country's total rice production. Clearly, to ensure water and food security, efficiencies in agriculture are required immediately. Rice production practices consume the largest share of water in the agricultural sector because most farmers practice continuous flooding throughout the cropping season. Therefore, optimization of rice production through new management practices that maintain rice yields with greater water-productivity is essential to ensuring the country's food security and access to freshwater for all.

Alternate wetting and drying (AWD), an irrigation scheduling technique for rice production, is a widely researched innovation for adapting agri-food systems to climate change, reducing environmental footprints, and ensuring a resilient and sustainable food production system (Lampayan et al., 2015; Carrijo et al., 2017; Rejesus et al., 2017). Alternate wetting and drying is a low-cost approach that enables farmers to adapt to increasingly water scarcity conditions, such as drought. When properly applied, AWD can increase overall farm production efficiency and mitigate GHG emissions (Rejesus et al., 2014; Valdivia et al., 2016; Allen and Sander, 2019). The Philippines is one of the focus countries where AWD was first piloted and disseminated in the early 2000s. It has been reported that $60 \%$ of the Philippine farming area is climatically suited to AWD (Sander et al., 2017). In terms of $\mathrm{CO}_{2}$ emissions, is estimated that AWD can potentially mitigate $91.2 \mathrm{MtCO}_{2}$ e within a 2015-2050 timeframe (USAID, 2015). For these reasons, the Philippine Government has taken steps to scale AWD in all national irrigation systems (NIS) and considers the technique a key adaptation and mitigation measure for meeting its Nationally Determined Contributions (NDC) (Arnaoudov et al., 2015), the official country commitment for achieving the goals of the Paris Climate Agreement. It also serves as the basis for long-term public investments and a potential instrument for accessing international climate finance. After two decades of scaling efforts, AWD adoption has been limited and much has yet to be achieved in terms of reaching the farmers nationwide. In 2016 , adoption was estimated at 60,559 farmers, covering 84,784 ha of land, which represents $<5 \%$ of the total irrigated area of 1.86 million ha (Rejesus et al., 2017). There is growing interest from the government and development partners in the scaling out of this technology.

This paper reviews the technological pathways to scaling AWD in the Philippines from 2000 to 2020 and aims to understand the different drivers and factors that influenced and constrained its success. This paper draws on the scaling-up framework of Hartmann and Linn (2008) and Cooley and Linn (2014) and innovation uncertainties framework of Seelos and Mair (2017) to assess how AWD scaling initiatives have interacted with different ecological and governance scales over time. Innovation uncertainty enables an understanding of how the innovation process accumulates and manages knowledge from its experience and use them to inform the potential scaling strategies.

\section{ANALYTICAL FRAMEWORK AND DATA}

\section{Analytical Framework}

Increasing the scale of adoption of technologies and practices is important for achieving widespread impact. But not all innovations are realized at scale, and if they are, this often happens in varied and context-specific ways. Scaling up spreads the beneficial use of technology, institutional, and/or capacity building practices within and across organizations and networks, from local to regional, national, and global levels (Menter et al., 2004; Millar and Connell, 2010). Scaling out, on the other hand, concerns the geographical expansion of the technology, practice, or systems change over time (Millar and Connell, 2010). Scaling out is often referred to as replication, dissemination, technology transfer, mainstreaming, and rolling out (Wigboldus and Leeuwis, 2013). Scaling deep relates to understanding and influencing cultural, behavioral, and relational contexts that are fundamental to introducing change (Moore et al., 2015). These 
efforts broadly involve capacity building and transformative learning to shape narratives and norms that are typically sustained through networks and communities of practices.

These are complex processes involving interrelated systems influenced by multiple actors, norms, and cultures (McLean and Gargani, 2019). Scaling tends to involve many interdependencies across actors and various bio-geophysical systems. Scaling out does not occur independently of scaling up/deep or vice versa; these are interlinked pathways that often complement and trigger each other. Scaling to a larger area, e.g., from farm fields to irrigated rice-based food systems, is often associated with greater uncertainty because institutional and contextual complexity grows as system boundaries enlarge (Wigboldus and Leeuwis, 2013). This situation makes scaling an inherently complex pursuit. Similarly, scaling technological innovations requires behavioral, organizational, or institutional change, which is often dictated by the contextual environment. This definition explains the reason transplantation of best practices, with a narrow awareness of knowledge uncertainties and untested assumptions, has been a surprising source of frustration and costly failure when implementing best practices in different geographies and contexts (Andrews et al., 2017; Woltering et al., 2019).

While innovation scaling is an intentional endeavor, it is a non-linear, iterative, and dynamic process that comes with inherent uncertainties. We view scaling as something that should not be understood merely in terms of quantitative metrics, such as adoption and impact. Scaling is also contingent on two outcomes: (i) fitness between the scaling context and requirements and (ii) actors learning to reduce the uncertainties in scaling strategies, which are the cause of failed attempts to scale technologies or practices.

To assess the scaling and adoption challenges of AWD, two frameworks were adapted for this study, namely, the "scaling up framework" (Hartmann and Linn, 2008; Cooley and Linn, 2014) and "innovation uncertainty framework" (Seelos and Mair, 2017; see Figure 1). The scaling up framework identifies the innovation, learning, and scaling up cycles as key components or phases that allow us to characterize the broad dynamic and interactive development of scaling pathways. The scaling up process is influenced by the dimension and vision of scale, drivers (forces that facilitate scaling), and spaces (opportunities created or barriers removed to enable scaling), operational modalities, installation of monitoring and evaluation (M\&E), and knowledge management (KM) with attention to scaling opportunities.

We complement this with the "innovation uncertainty framework," which identifies contextual factors that influence the success of innovation scaling. These factors are problem frame, adoption, solution development, unintended consequences, alignment with identity, and managerial uncertainty. Our analysis was performed by comparing, in an evaluative manner, the levels of uncertainty (or the lack of accuracy) of assumptions surrounding how scaling AWD would happen and how knowledge is accumulated and managed to decrease uncertainties against the resulting outcomes and impacts. A key hypothesis here is that the conditions associated with these factors are not static or necessarily linear across the piloting and scaling spectrum. Their definition and scope usually change when you move to scaling. Effectiveness of scaling interventions is evaluated based on the responsiveness and capability to adapt to these uncertainties; through productive use of evidence of what works and what does not in what context.

\section{Data Collection and Limitations}

This paper draws primarily on secondary data sources and analysis of peer-reviewed articles, project documents and reports, and evaluations. The data covers five major programs/projects in the Philippines that targeted development, piloting, and scaling of AWD technology in the Philippines from 2000 to 2020 (see Table 1).

While this review covers a wide range of evidence on AWD scaling in the Philippines, it is by no means complete or exhaustive in terms of the data we think is available. The distribution of data also determined the availability of institutional memory to inform this study. This data gave us a better, though partial, glimpse of the rationale behind the scaling programs, and the associated adaptation of activities along the way.

\section{RESULTS AND DISCUSSIONS}

\section{Alternate Wetting and Drying Technology}

The early development phase of AWD was initiated in 2000 through IRRI's Irrigated Rice Research Consortium (IRRC). It started as a problem-oriented initiative to respond to farmers' need to meet irrigation requirements despite water scarcity trends. The principle behind AWD draws from the logic of controlled irrigation. Controlled irrigation (CI) is an irrigation scheduling practice in which farmers apply water to their fields for a number of days after the ponded water disappears (Palis et al., 2004). The novel component of AWD involves the development of a low-cost field water tube for monitoring the depth of ponded water and science-based guidance for managing the depth of the water below the surface of the soil to optimize water savings without incurring yield penalty (Bouman and Tuong, 2001; Belder et al., 2004). With the field water tube, farmers can use CI on their fields and monitor the ponded water depth to manage the water levels. To apply AWD, farmers must intermittently flood and dry their plots by maintaining a "safe" threshold water depth of $15 \mathrm{~cm}$ (below the surface), except during the flowering stage when farmers must maintain the pond water depth at $5 \mathrm{~cm}$ above ground from 1 week before to 1 week after flowering (Bouman et al., 2007).

Alternate wetting and drying technology also holds promise for sustainably linking water use, energy, and food production to deliver water savings at the irrigation systems level. Improving the water productivity at the irrigation system level through the application of AWD can enable water for other sectoral uses such as domestic, industrial, and energy. However, for this to happen, farmers must collectively practice safe AWD within the irrigation scheme. Based on suitability assessment, AWD is climatically suited to more than $90 \%$ in the dry and about $34 \%$ in the wet season (Sander et al., 2017). This highlights the great potential for technology scaling and adoption in the country. 


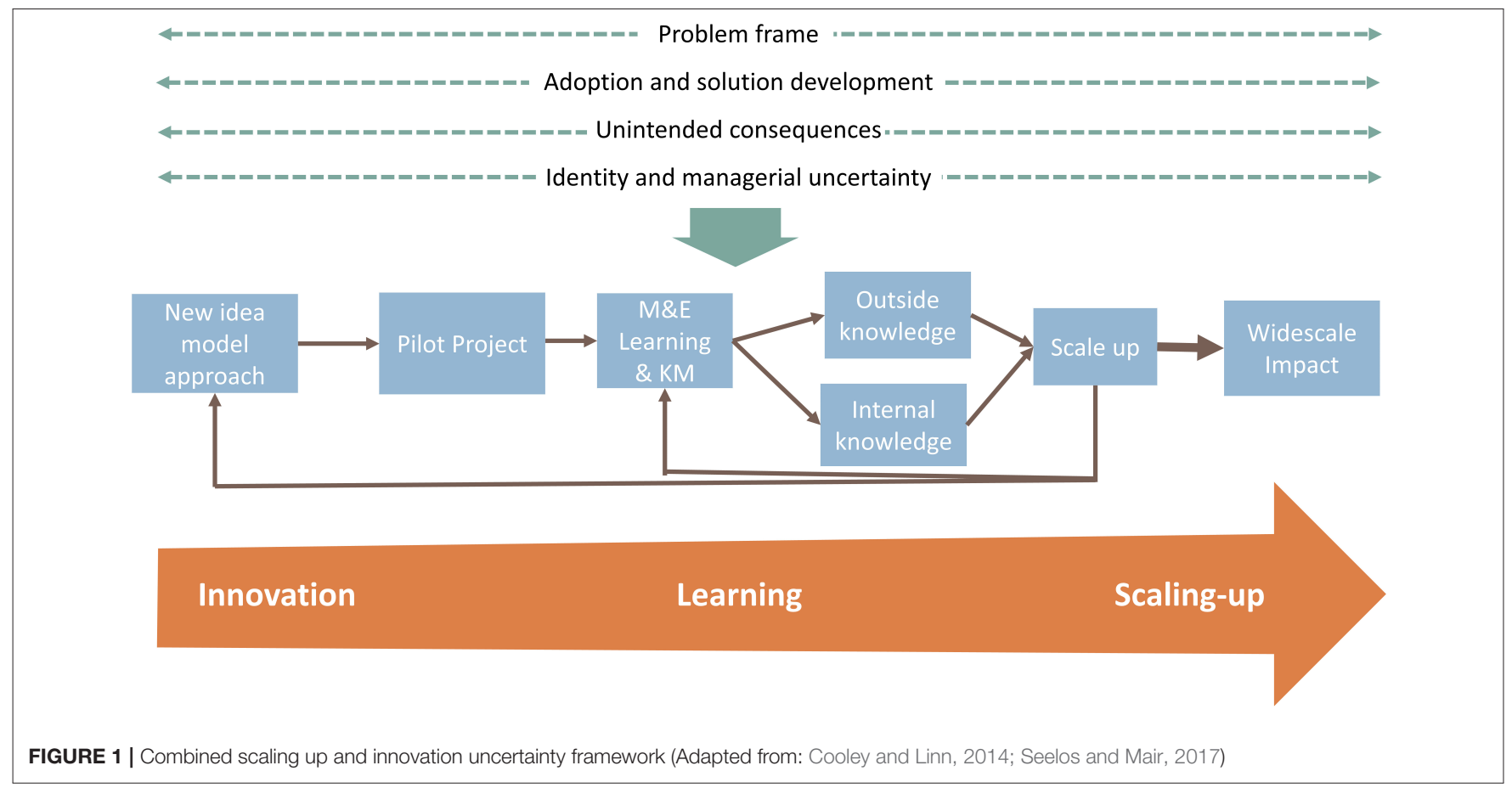

TABLE 1 | Key projects that developed and scaled AWD technology in the Philippines, 2000-2020.

\begin{tabular}{|c|c|c|c|c|c|}
\hline Project acronym & IRRC & $\begin{array}{l}\text { GHG } \\
\text { measurement }\end{array}$ & AssoTech & AWD IA & WateRice \\
\hline Period & 2001-2012 & 2010-2012 & 2013-2017 & 2016-2017 & 2017-2021 \\
\hline Area & Region 3 and 7 & Region 3 & $\begin{array}{l}\text { Regions 1-13 and } \\
\text { CAR }\end{array}$ & Region 5 & $\begin{array}{l}\text { Regions 1, 2, 3, 6, } \\
\text { and } 12\end{array}$ \\
\hline Interventions & $\begin{array}{l}\text { Technology } \\
\text { development, } \\
\text { farmer } \\
\text { field-testing, } \\
\text { multi-stakeholder, } \\
\text { training-of-trainers }\end{array}$ & $\begin{array}{l}\text { Field experiments, } \\
\text { training }\end{array}$ & $\begin{array}{l}\text { Farmer field demo, } \\
\text { seminars, training }\end{array}$ & $\begin{array}{l}\text { Randomized } \\
\text { controlled trials } \\
(\mathrm{RCT}) \text {, modeling, } \\
\text { and FGDs }\end{array}$ & $\begin{array}{l}\text { Technology } \\
\text { development and } \\
\text { testing, training }\end{array}$ \\
\hline Implementers & IRRI, PhilRice, NIA & IRRI, PhilRice & IRRI, PhilRice, NIA & IRRI, PhilRice & IRRI, PhilRice, NIA \\
\hline Project type & $\begin{array}{l}\text { Technology } \\
\text { development, } \\
\text { adaptation, } \\
\text { piloting to scaling } \\
\text { up and out }\end{array}$ & $\begin{array}{l}\text { Discovery, } \\
\text { Proof-of-concept }\end{array}$ & Scaling out & Proof-of-concept & $\begin{array}{l}\text { Discovery, } \\
\text { Proof-of-concept } \\
\text { and piloting }\end{array}$ \\
\hline
\end{tabular}

Source: Authors.

\section{Economic Benefits of AWD Adoption From Field Trials in the Philippines}

We summarize the findings of seven economic studies that have evaluated the benefits of safe AWD from the pilot to replication stages (see Table in Supplementary Material). Most of these studies conducted participatory field demonstrations and trials in pump irrigation systems (i.e., tube wells) in Region III (Tarlac, Nueva Ecija). A few studies were conducted in gravity canalbased systems in Region V (Camarines Sur) and Region VII (Bohol). These studies employed before and after, with, and without approaches, or both, in which researchers had farmers test the application of traditional irrigation through continuous flooding and safe-AWD practices side-by-side on two plots (Palis et al., 2004, 2017; Sibayan et al., 2010). This approach is also considered an effective demonstration tool for promoting and diffusing the technology because farmers are more likely to test out a technology when they see it for themselves (Hoffmann et al., 2007).

The results of these studies show that the direct benefit of safe-AWD is irrigation water savings. In both pump- and canalbased irrigation systems, AWD reduces water use by $16-28 \%$ compared with traditional continuous flooding. Water saving is also associated with a $38-48 \%$ reduction in the time farmers require to irrigate their fields. Other potential effects of AWD on 
water productivity, crop yield, and income were also investigated. However, safe AWD was found to have no significant effect on yield. In terms of income effects, safe AWD increased farmers' net returns in pump-irrigated systems through savings on the fuel costs associated with irrigation of up to $40-46 \%$, or USD 52 to USD 102 per ha. However, in gravity systems, these studies synonymously concluded that AWD has no significant impact on farmers' income. This finding may be due to difficulty excluding unintended users from accessing irrigation systems, even with administrative enforcement of irrigation scheduling. Another reason is that irrigation infrastructure and collective management of the physical and institutional conditions determines the excludability and predictability of water used by farmers (Pearson et al., 2018). In canal-based systems, the reduction in irrigation use by upstream farmers due to AWD adoption has resulted in a more reliable water supply to downstream farmers, which eventually led to improved ability to irrigate their crops (Sibayan et al., 2010; Rejesus et al., 2014, 2017; Valdivia et al., 2016; Palis et al., 2017). From 2005 to 2010, it is estimated that 197 farmers increased the extent of their irrigated farm area on average by 0.2 ha per farmer, resulting in increased production from an average of $377 \mathrm{~kg} \mathrm{ha}^{-1}$ in dry season and $256 \mathrm{~kg} \mathrm{ha}^{-1}$ in wet season (Valdivia et al., 2016).

\section{Drivers of Scaling}

Throughout the AWD scaling pathway, the relevance of the technology in relation to the policy priorities and mandates of the Philippine Government in the agriculture and irrigation sector was clear and robust. This understanding drove a longstanding partnership and policy support from the Philippine Department of Agriculture (DA) and National Irrigation Administration (NIA).

We looked at various factors that could play a role in AWD scaling pathway. Figures 2A,B show how El Niño years have often coincided with stifled rice production in the country. This relationship is found more pronounced in strong El Niño phases characterized by delayed on-set of the rainy season and rice planting, diminished irrigation and reduced harvestable areas (Dawe et al., 2009; Sutton et al., 2019). The Figure 2C indicates, however, that price, during these El Niño years, moves independently of the annual rice production levels because of trade and supply side measures at play (Dawe et al., 2009).

The global price spike in 2007-2008, which tripled from USD 335 to over USD 1,000 per metric ton in a matter of 6 months, created immense pressure on the country-where rice is the main staple food-to ensure rice availability and accessibility (Manzano and Prado, 2014). Following the rice crisis in 2008, the DA initiated programs to meet rice productivity targets with limited water resources and dwindling irrigation infrastructure, which led to the launch of its Food Self-Sufficiency Program (Rejesus et al., 2014; Inocencio and Barker, 2018).

Improving water productivity through AWD was one of the solutions used to address these problems upfront. Alternate wetting and drying also offered low-cost solutions without significant investment in irrigation infrastructure and showed great potential to improve water productivity. The technology's proposition together with concerns over the rice price crisis and drought events attracted the interests of government agencies, NGOs, and farmers. This backdrop and the direct relevance of AWD to the DA and NIA mandates provided a firm framework for collaboration between the two agencies and the subsequent integration of AWD into their national programs (Rejesus et al., 2014; Lampayan et al., 2015).

In 2016, with increasing concerns over climate change and commitments for adaptation, AWD technology became a promising option under the government's climate change mainstreaming efforts in the agriculture sector (Arnaoudov et al., 2015). Alternate wetting and drying was proposed as one of the DA's priority adaptation and mitigation measures for the country's NDC. The NDC not only outlines the country's conditional and unconditional commitments to international climate action to limit warming within $1.5-2^{\circ} \mathrm{C}$ above pre-industrial levels, it also provides opportunities for developing countries to tap into available climate financing to drive transformations toward climate-resilient agri-food systems.

\section{Pathways to Scale}

The analysis of this study found that AWD scaling pathways underwent iterative cycles of technological adaptation, promotion, and scaling. These pathways are characterized by the following interdependent mechanisms: (i) multistakeholder innovation platforms and adaptive research; (ii) capacity building and participatory dissemination; and (iii) policy support and institutional arrangements. The sequence of activities and scaling outcomes is described in Figure 3.

\section{Development and Introduction of Technology Through Multi-stakeholder Innovation Platform}

Alternate wetting and drying was developed through a multi-stakeholder innovation platform called the Water-Saving Workgroup as part of the IRRC in early 2000. The network brought together key actors, including national agricultural research and extension systems, farmer irrigation cooperatives, and individuals with a shared vision of spreading knowledge of promising rice technologies to improve farmers' income and productivity (Lampayan et al., 2014; Rejesus et al., 2014; Palis et al., 2017). The working group's main goal was to pilot test and disseminate AWD. The initial participatory adaptive trials were conducted in a pump-based deep-well irrigation system (Palis et al., 2004). Although positive results were observed in terms of irrigation water savings, farmers were apprehensive about some aspects of the logic behind AWD, such as reducing water use and seeing resulting cracked soils, which were a stark contrast to their traditional practice of continuous flooding (Palis et al., 2004, 2017). The technology was also viewed by farmers as both knowledge and labor intensive (Yamaguchi et al., 2019). It required them to tend to their fields more often and follow an established irrigation calendar strictly until harvest (Arnaoudov et al., 2015; Palis et al., 2017). Because of this perception and out of fear of reducing their yields, some of the farmers in the group started to illicitly tap on the irrigation circumventing the agreed arrangements to follow AWD practice (Palis et al., 2004). 
A

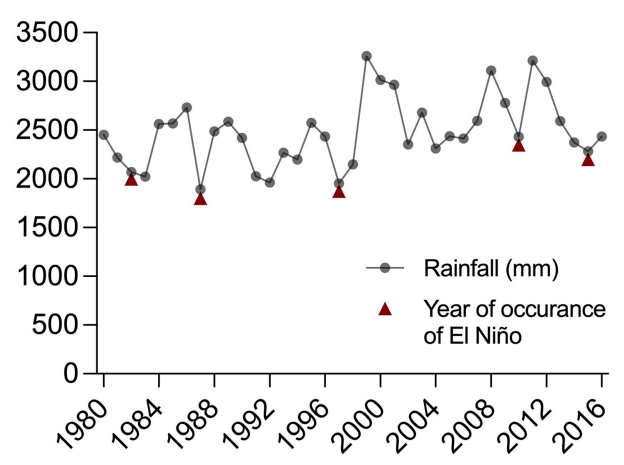

B

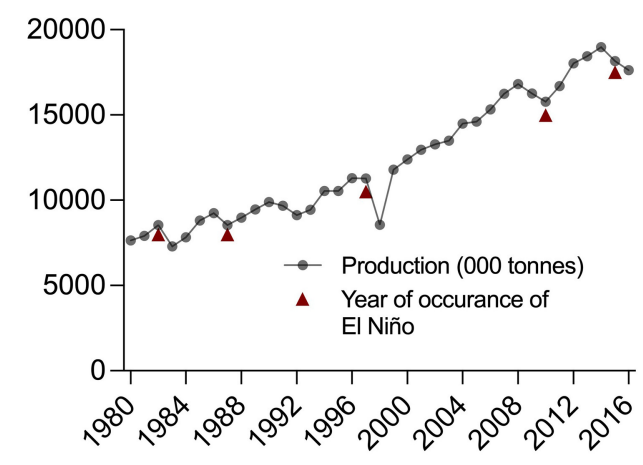

C

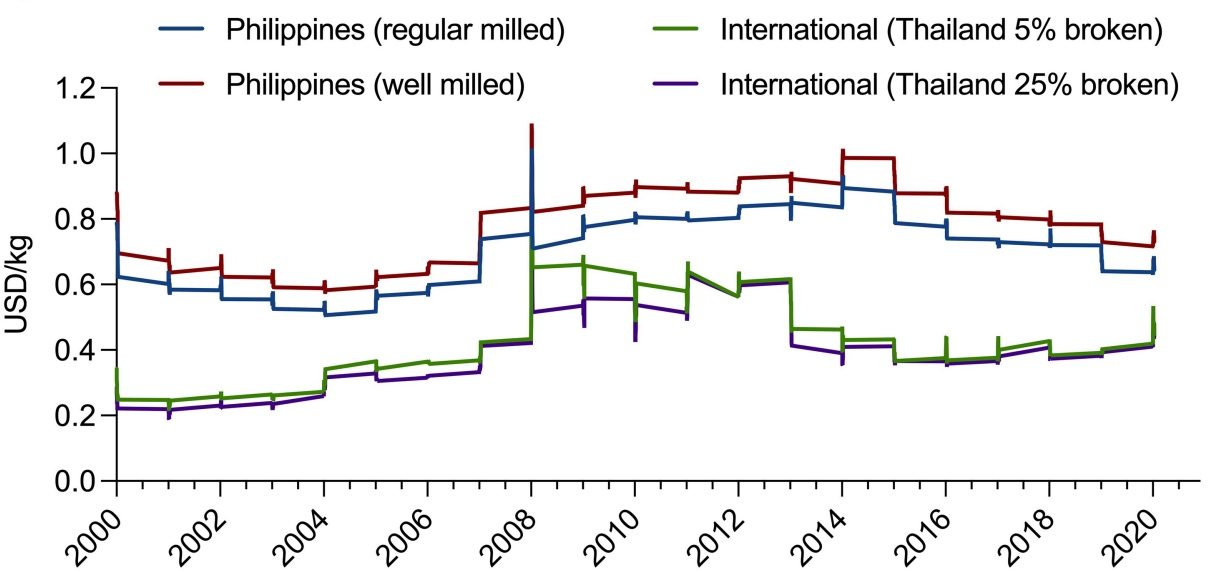

FIGURE 2 | Potential drivers of various AWD initiatives in Philippines including (A) rainfall and El Niño cycles, (B) total rice production, and (C) rice price (Sources: World Bank, 2021; FAO STAT; FAO GIEWS FPMA; IMF-IFS; OCHA, 2015).

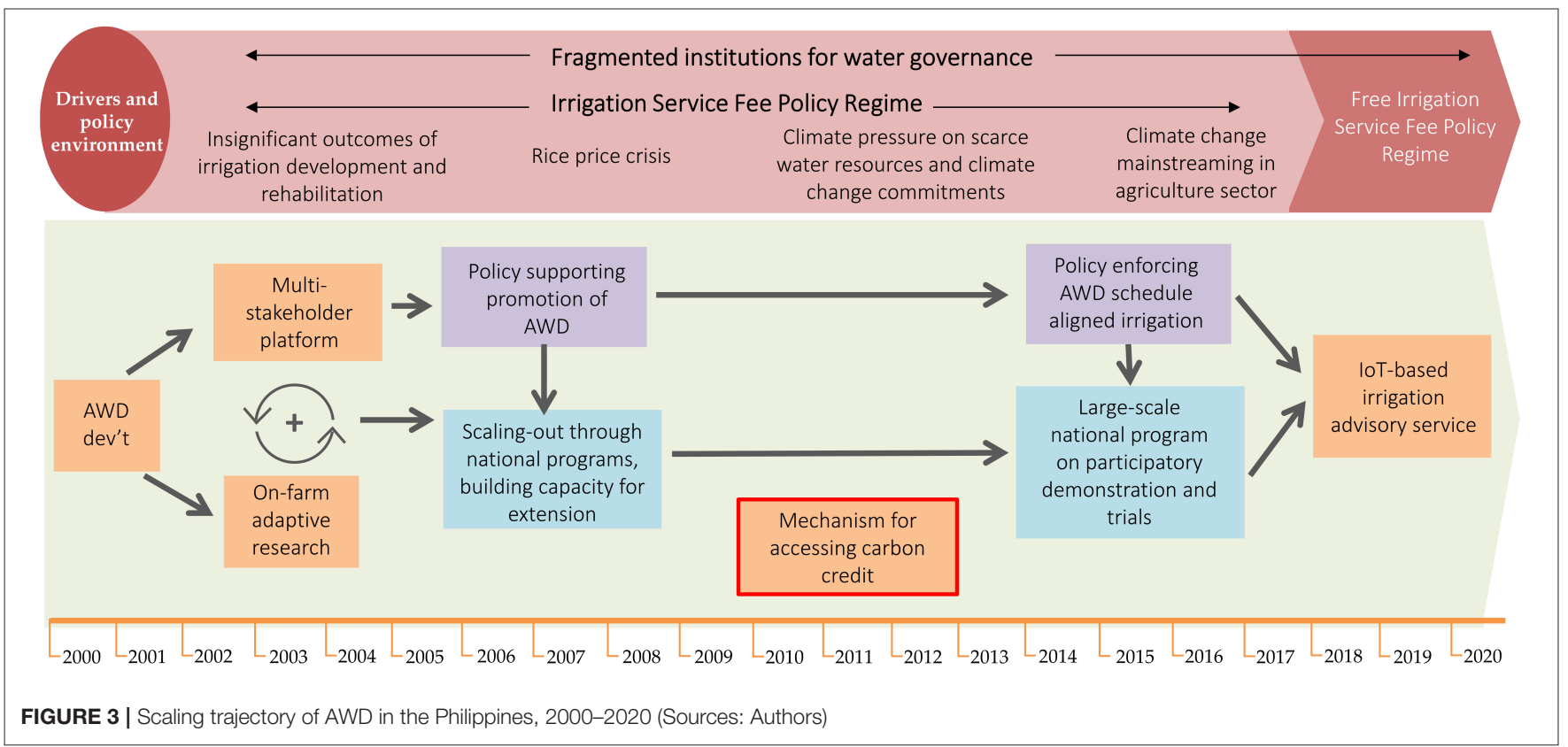




\section{Scaling-Out AWD Through Participatory Demonstration, Capacity Building, and Enabling Policies}

To address the challenge of lack of trust and improve scaling out, an incentives-based model to improve adoption was also tested by introducing a payment scheme that internalized the costs of fuel that farmers consume to irrigate their fields (Palis et al., 2004). Along with incentives, the technology was further improved to avoid stress at the critical growth stage, and this technique was called "safe-AWD" (Rejesus et al., 2014). This resulted in increased trust among the irrigation cooperatives (Palis et al., 2017). With greater confidence in the use and benefits of safe-AWD, the irrigators' association decided to diffuse or scale out the innovation to the entire service area of the targeted irrigation scheme (about 72 deep-well systems covering 3,355 ha for 2,256 farmer members; Lampayan et al., 2009; Rejesus et al., 2011). The scaling effort in deep-well pumps also introduced irrigation rotations that intentionally approximated farmer irrigation schedules consistent with the safe-AWD technique.

In the mid-2000s, AWD was tested in gravity-based NIS in the Bohol Irrigation System (BIS) and the Upper Pampanga River Integrated Irrigation System (UPRIIS). National irrigation systems includes large irrigation systems that exceed 1,000 ha, typically ranging from about 30,000-110,000 ha (Clemente et al., 2020). Similar to pump irrigation systems, challenges to convincing the farmers to test the technology were also encountered in the gravity-based system. Similar to experience in other countries like Bangladesh, in this system, there was no associated economic gain for adopting AWD because farmers pay a fixed irrigation fee that is determined by the size of the irrigated area (Arnaoudov et al., 2015; Pandey et al., 2020). The incentive-led adoption model was also tested in the gravity system by guaranteeing compensation for whatever yield loss volunteer farmers might incur by providing agricultural inputs and enough water for irrigation (Sibayan et al., 2010; Regalado et al., 2018). The replication trials were subsequently scaled out in BIS in $2005(\sim 4,000 \mathrm{ha})$ and UPRIIS in 2007 (16,000 out of 82,000 ha) (Rejesus et al., 2014; Lampayan et al., 2015; Palis et al., 2017).

The success of AWD in both pump- and gravity-based systems led to initiation of scaling up efforts through policy support by the DA and NIA, which encouraged the adoption of AWD. In 2009, the DA issued an administrative order promoting AWD as a water-saving measure in its agricultural programs (Rejesus et al., 2014; Palis et al., 2017). This was complemented by training and farmer field school initiatives for about 3,000 trainers, technicians, academicians, and farmers in many parts of the country through local government units (LGUs) and village partners (Rejesus et al., 2014; Palis et al., 2017). In 2016, the NIA issued Memorandum Circular 36 promulgating AWD's adoption in all NISs in the Philippines through irrigation scheduling (Palis et al., 2017). Along with the DA's national efforts, the AWD network membership grew to include national and local state universities, agricultural training and extensions, and LGUs. This platform served as a vehicle for building synergistic interactions and stimulating institutional learning among members and across national borders that helped grow the network, which led to the fast-track dissemination and engendered scaling up of the technology. Alternate wetting and drying scaling out efforts peaked from 2013 to 2017, during which AWD was intensively disseminated all over the country. The scaling program bundled together AWD technology with other income-enhancing technologies, such as drum seeders for row seeding, certified seeds of recommended varieties, and crop managers in large- and small-scale irrigation systems (Regalado et al., 2018). The scaling activities were administered through participatory-cum-demonstration trials.

\section{Scaling Through a Model for Accessing Clean Development Incentives}

In 2015, the DA also considered adopting AWD in its flagship program focused on strengthening Adaptation and Mitigation Initiatives in Agriculture (AMIA) as a strategy for the irrigated rice sector, through which it intends to manage 750,000 ha of irrigated fields under AWD (Arnaoudov et al., 2015). Because of its GHG mitigation benefits, AWD was seen as a promising tool for adaptation to and mitigation of climate change and to access carbon credits in the United Nations Framework Convention on Climate Change (UNFCCC) Clean Development Mechanism. The clean development mechanism (CDM) is one of the Kyoto Protocol approaches for undertaking environmentally sustainable activities. A methodology for calculating GHG emissions was developed for accessing carbon-based payments that would create greater incentives for farmers to collectively adopt safe-AWD on a larger scale (Siopongco and Wassmann, 2013). After UNFCCC approval of the methodology in 2011, which did not require the implementers to conduct any GHG measurements to prove farmer compliance, this innovation supposedly simplified adoption of the methodology and made it less costly. However, due to challenges in designing feasible institutional arrangements for carbon-based payment, it did not move beyond the piloting stage.

\section{Scaling Through Integrated Irrigation Advisory Mechanisms}

The advent of low-cost sensor technologies provided opportunities for improving AWD adoption. This primarily provided a way to address AWD farmer adoption challenges, knowledge, and labor, the unreliability of water supply result in a mismatch of the timing AWD, and, inefficiencies in coordination and water management across administration (Regalado et al., 2019). The outcome of this learning was the development and piloting of AutoMon ${ }^{\mathrm{PH}}$, an Internet-of-Things-(IoT)-powered decision support tool that provides irrigation advisory service to farmers and irrigation managers (IRRI and PhilRice, 2020), making it easier to adopt AWD, efficiently manage water demand and delivery, and ultimately, sustainably manage water resources. This technology is being benchmarked in different irrigation contexts, from irrigation systems with relatively good water control (pump-based) to gravity-based systems where collective action is required for managing the water. However, the AutoMon ${ }^{\mathrm{PH}}$ based solutions is still at a concept validation stage and haven't generated any evidences of scaling of AWD. 


\section{Binding Constraints to Impact at Scale}

Even though there is some evidence of AWD scaling in smallscale systems and demonstration of it in large-scale irrigation systems, there is a growing mix of evidence suggesting that the long-term impacts of AWD are minimal. In terms of reach and adoption of AWD, there is data available detailing several years its use. However, the available studies were done independently and have different measurement approaches, which are not substantive enough to provide a systematic picture of the adoption but nevertheless offer a useful starting point to provide some indication of the trends. In the early stages (2002-2004), AWD piloting was estimated to have reached a cooperation level of 3,355 farmers, and this number increased to 20,000 from 2005 to 2007 during the scaling out (Rejesus et al., 2014; Palis et al., 2017). Adoption of AWD increased from 93,014 farmers in 2011 (Dixit et al., 2016) to 140,000 in 2013 (Arnaoudov et al., 2015), and decreased to 84,784 in 2016 (Rejesus et al., 2017).

This study analyzed the existing evidence to assess how assumptions on which scaling interventions are based capture sufficient knowledge about areas of innovation uncertainties (see Table 2).

\section{Framing Problems From a Techno-Centric and Unidimensional Perspective}

Water scarcity is a multifaceted issue, and this certainly applies to irrigation systems to most of the countries (Breen et al., 2018). This definition gives the backdrop opportunities to address irrigation water scarcity through efficient irrigation technologies and practices, becoming the entry point for scaling AWD technology. The rationale for scaling AWD is based on a problem definition of prevalent irrigation water scarcity, driven to extremes by climate change conditions, that affects farmers and which could be addressed if not for the lack of access and the capacity to apply the technology.

Framing the problem in this way, however, is techno-centric and uni-dimensional, and it assumes that scaling AWD can be achieved if farmers decide to adopt it and have the technical know-how and skills to apply the AWD technique (Breen et al., 2018; De Loë and Patterson, 2018; Glover et al., 2019). Scaling strategies that exemplify this have been largely characterized by information sharing, training, technology demonstrations, and transfer. While adoption of AWD does indeed concern individual farmers, scaling AWD goes beyond the level of the individual, and the problem of irrigation water involves causes that are much deeper than lack of water. The intentional shift from piloting to scaling also enlarges not only the geographical scope but also its systems of interest. Moving to scaling in irrigation systems not only involves individual farmers' decisions, but also incentives for adoption and cooperation, and adequate management and sufficient quality of irrigation systems are necessary conditions. Therefore, scaling goes beyond individualistic factors to include the institutions and systems that ensure the social and technical conditions necessary for irrigation provisioning, such as irrigation infrastructure, institutional arrangements for irrigation water allocation and enforcement, water pricing systems, and monitoring and enforcement (Araral, 2009; Schut et al., 2020).
Fragmented and multilayered institutional arrangements coupled with a weak capacity to enforce policies characterize the governance regime for water in the Philippines (Rola et al., 2018). There is no central planning body for water in the country. Instead, the mandate for governing water is spread over multiple water institutions. Specific to irrigation governance, there are at least 13 national agencies that have irrigation-related functions or mandates (Rola, 2019). The irrigation governance landscape is currently mired with overlaps and redundancies that result in uncoordinated planning and development of irrigation systems. For example, irrigation master planning and development are undertaken by the NIA and the Bureau of Soils and Water Management (BSWM). The Department of Environment and Natural Resources River Basin Control Office (DENR-RBCO) also has its own master plan for river basin management, which has identified potential irrigation development sites. Moreover, the NIA is also responsible for water use management and watershed management in areas where large irrigation systems are located; this is also the mandate of the DENR forest management bureau and the National Power Corporation which governs hydropower. However, due to the lack of human resources as a result of the rationalization of its staff, the NIA could not adequately perform its watershed management functions (Rola et al., 2020). The quality of irrigation service provisioning and water quality can also be attributed to weak institutional enforcement and governance issues (Clemente et al., 2020). Shortages of downstream irrigation are often caused by unabated illegal access and locking of gates, illegal settlers, pumping/dumping of garbage/turnouts, and poor canal maintenance.

Farmers not only experience water scarcity, but because of increasing climate variability, they also suffer from the extremes of both poor water availability in dry season and flooding in wet season. The most common water supply problem is water shortage during the dry season. In the dry season, irrigation associations implement remedial measures such as construction of re-use dams and shallow tube wells. They also implement AWD as a coping mechanism rather than being a deliberate decision to adopt AWD to improve water productivity and increase irrigation availability downstream-similar to the findings in Zhange Irrigation System (Mushtaq et al., 2006). During the wet season, some major systems suffer from flooding which limits cropping to dry season (Clemente et al., 2020). Excessive siltation in dams and canals is also a major problem in large irrigation systems; in some areas, an 8-m wide main canal may be reduced to $1-\mathrm{m}$, thus reducing the available irrigation water supply (Clemente et al., 2020). The literature points to these factors as an explanation of why, despite considerable investment in irrigation development and rehabilitation-accounting for a third of the total expenditure in agriculture since the 1960s-the levels of cropping intensity over the years have not significantly improved (Delos Reyes, 2017).

\section{Limits of "Technology Push" to Scaling}

Two essential conditions for scaling AWD technologies are whether farmers are willing to adopt them and whether the required operational and environmental conditions are in 
TABLE 2 | Overview of AWD scaling strategies (thus far) and gaps.

\begin{tabular}{|c|c|c|c|}
\hline $\begin{array}{l}\text { Innovation } \\
\text { uncertainties }\end{array}$ & Findings of the review & $\begin{array}{l}\text { AWD scaling assumptions and } \\
\text { interventions }\end{array}$ & Analysis of scaling gap \\
\hline $\begin{array}{l}\text { - How is the } \\
\text { problem of } \\
\text { irrigation understood? }\end{array}$ & $\begin{array}{l}\text { - Poor irrigation management is } \\
\text { caused by multiple factors: poor } \\
\text { water governance and } \\
\text { management, poor irrigation } \\
\text { infrastructure or water delivery } \\
\text { systems, and non-compliance } \\
\text { toward institutional arrangements. } \\
\text { - Poor irrigation development and } \\
\text { management results into dwindling } \\
\text { quantity and reliability of } \\
\text { irrigation supply. }\end{array}$ & $\begin{array}{l}\text { - Presence of and climate-induced } \\
\text { irrigation water scarcity are seen as } \\
\text { main causes of low irrigation. } \\
\text { - Technologies or practices that } \\
\text { increase water productivity are } \\
\text { considered a stand-alone solution } \\
\text { to addressing irrigation water } \\
\text { scarcity. } \\
\text { - Practicing AWD can increase } \\
\text { availability of irrigation water and } \\
\text { thereby crop intensity and } \\
\text { irrigation coverage. }\end{array}$ & $\begin{array}{l}\text { - There appears to be a problem with } \\
\text { framing and sufficiency solution mismatch, } \\
\text { particularly in gravity-based systems. } \\
\text { - AWD is only partially effective in resolving } \\
\text { water scarcity in irrigation systems } \\
\text { experiencing declining irrigation } \\
\text { infrastructure quality and unreliable quality } \\
\text { of irrigation provisioning. }\end{array}$ \\
\hline $\begin{array}{l}\text { How are the } \\
\text { facilitating and } \\
\text { hindering } \\
\text { factors to farmer } \\
\text { adoption of } \\
\text { AWD understood? }\end{array}$ & $\begin{array}{l}\text { - } \text { AWD is a knowledge-intensive } \\
\text { technology and its logic contrasts } \\
\text { with traditional irrigation. } \\
\text { - Adoption of AWD is non-binary. } \\
\text { - AWD does not affect yield, but it } \\
\text { can increase farm irrigation } \\
\text { coverage. } \\
\text { - Economic incentive exists to adopt } \\
\text { AWD in pump irrigation systems. } \\
\text { - Strong institutional enforcement is } \\
\text { key to AWD adoption in } \\
\text { canal-based systems. }\end{array}$ & $\begin{array}{l}\text { - Participatory field trials, with a } \\
\text { guarantee of compensation for } \\
\text { yield loss, were taken as an } \\
\text { approach to addressing the initial } \\
\text { apprehensions of farmer } \\
\text { cooperators and are coordinated } \\
\text { through the farmer associations. } \\
\text { - Purposive selection of volunteer } \\
\text { farmer cooperators, with conducive } \\
\text { farm conditions, in field trials of } \\
\text { AWD helped control for context } \\
\text { variability in farm irrigation contexts. }\end{array}$ & $\begin{array}{l}\text { - Factors of farmer adoption are known, but } \\
\text { there is a lack of knowledge about how to } \\
\text { make AWD scaling work in contexts beyond } \\
\text { controlled favorable field trial conditions. } \\
\text { - While institutional enforcement is an } \\
\text { important mechanism for adoption, this } \\
\text { knowledge does not feature as a major } \\
\text { component of AWD scaling strategy. }\end{array}$ \\
\hline $\begin{array}{l}\text { - How are } \\
\text { requirements for } \\
\text { successful } \\
\text { scaling of } \\
\text { irrigation } \\
\text { development } \\
\text { and } \\
\text { management } \\
\text { impact understood? }\end{array}$ & $\begin{array}{l}\text { - Adequate irrigation infrastructure is } \\
\text { necessary for scaling AWD. } \\
\text { - Public institutions lack adequate } \\
\text { capacity and resources for } \\
\text { extension and monitoring of AWD. } \\
\text { - Water pricing scheme determines } \\
\text { the incentives for farmer adoption } \\
\text { of AWD and compliance to } \\
\text { institutional arrangements. }\end{array}$ & $\begin{array}{l}\text { - Scaling strategy focused on } \\
\text { increasing geographic coverage } \\
\text { through participatory } \\
\text { demonstration and information } \\
\text { dissemination. } \\
\text { - Suitability analysis is available for } \\
\text { targeting and prioritizing areas for } \\
\text { scaling AWD in the country; this } \\
\text { study used soil quality and climate } \\
\text { information as criteria for suitability. } \\
\text { - Mainstreaming of AWD through the } \\
\text { DA and NIA policy and programs } \\
\text { promoting the technology to } \\
\text { the farmers. }\end{array}$ & $\begin{array}{l}\text { - AWD scaling strategy is limited and does } \\
\text { not address other key scaling concerns and } \\
\text { new challenges brought about by FISA. } \\
\text { - The suitability analysis does not consider } \\
\text { the institutional and infrastructural } \\
\text { characteristics of irrigation systems, which } \\
\text { are far more critical as determinants of } \\
\text { whether AWD can be } \\
\text { scaled-out successfully. }\end{array}$ \\
\hline $\begin{array}{l}\text { What are the } \\
\text { unintended } \\
\text { consequences } \\
\text { and trade-offs } \\
\text { related to the } \\
\text { use of AWD? }\end{array}$ & $\begin{array}{l}\text { - AWD adoption is interdependent } \\
\text { with other livelihood and water use } \\
\text { systems. } \\
\text { - Benefits, trade-offs, } \\
\text { facilitating/hindering factors, } \\
\text { unintended consequences of AWD } \\
\text { adoption happen at } \\
\text { different scales. }\end{array}$ & $\begin{array}{l}\text { - The farmer irrigation dynamics in } \\
\text { pump irrigation systems were } \\
\text { well-studied, to some extent; } \\
\text { cross-sectoral interactions with } \\
\text { different actors and sectors were } \\
\text { explored. } \\
\text { - Farmer-level and sector-level } \\
\text { trade-offs were explored. }\end{array}$ & $\begin{array}{l}\text { - Knowledge of the trade-offs and } \\
\text { cross-scale concerns of AWD adoption is } \\
\text { explored but has not been translated into } \\
\text { strategy and operation of scaling theory of } \\
\text { change. There is still insufficient } \\
\text { understanding of the cross-scale tradeoffs } \\
\text { of AWD. }\end{array}$ \\
\hline
\end{tabular}

Source: Authors.

place for AWD adoption at scale. The main scaling approach undertaken with AWD technology has been dissemination integrated with participatory technology demonstration trials. National partners played an important role in promoting and diffusing the technology through farmers' field days and demonstration visits. Like many other natural resource management practices, AWD technology is knowledge-intensive (Yamaguchi et al., 2019). Its adoption is not straightforward or binary when compared with other crop management practices (Sumberg, 2016; Glover et al., 2019). Alternate wetting and drying application lies along a spectrum of consistency in the management of subsurface water levels within safe thresholds. This work not only requires farmers to monitor water levels and corresponding irrigation adjustments, but also reliable water supply (which depends on a functional water governance structure).

Farmers are risk-averse in terms of testing AWD technology because the logic behind how the technology works starkly contrasts with their traditional practice of continuous flooding. While AWD can improve irrigation crop intensity and total productivity, AWD does not directly impact yield improvement, particularly for gravity-based irrigation systems, However, 
participatory field demonstrations have shown that AWD has been successfully adopted in pump-irrigation systems where farmers experienced the input cost savings from fuel expenses (Palis et al., 2004; Regalado et al., 2018). This shows the importance of predictability and the ability to exclude unintended users from consuming water resources, and presence of an institution for access rule enforcement (Araral, 2009). However, it is important to note that the coverage of pumpirrigation systems in the country is minimal at $12 \%$ and (Delos Reyes, 2017) and the largest share (75\%) of farmers in irrigated ecosystems are still using gravity-based systems (Inocencio et al., 2020). In gravity-based irrigation, adoption of AWD has been extremely limited. In the early stages of technology development, it was hypothesized that adoption of AWD in a gravity-based system would result in savings on irrigation fees. In 2017, the irrigation water pricing scheme was revised with the introduction of the Free Irrigation Service Act (FISA). Free Irrigation Service Act removed NIA's revenue from irrigation fees since it is now subsidizing irrigation fees for smallholder farmers with farms of 8 ha and less. This policy may potentially have created a disincentivizing effect in terms of the NIA's motivation to improve its rehabilitation and irrigation system quality and performance (Briones et al., 2019). The multiplicity and conflicting nature of the objectives beset the current mandate of NIA.

The ability to exclude users, enforce compliance mechanisms and water pricing is much clearer in pump-based irrigation systems. Large canal-based systems are highly prone to illegal water tapping, and compliance is much difficult given the scale of the irrigation system. Most of these irrigation infrastructures are already 30-40 years old and are affected to varying degrees by deterioration, siltation, and damage (Clemente et al., 2020; Inocencio et al., 2020). Other challenges related to infrastructure include inadequate head control structures, misplaced and inappropriate flow control and off-take structures, direct offtaking of farm ditches from main canals, inadequate protection of sluice gates and main takes from siltation and very high servicearea-to-farm-ditch and turnout ratios. In addition, unreliable estimates of water demand stem from a lack of data and a lack of capacity to measure and determine key water balance requirements, for instance, some of the water supply data available at NIA study site were as much as 50 years old (Rola et al., 2020).

Moreover, there are no updated and interoperable databases or data collections to support real-time decision-making for water resources, conflicts, and enforcement of various waterrelated laws (Hall et al., 2015). The M\&E of irrigation system performance rest with the NIA and BSWM through the DA's respective regional field office. The conduct of $\mathrm{M} \& \mathrm{E}$ is weak, and it significantly lacks human resources along with the application of innovation tools, despite the availability of modern technologies like GIS (Rola et al., 2020). Currently, there is one technical officer per 2,000 ha of irrigation area. These problems cripple coordinated planning, implementation, and $\mathrm{M} \& \mathrm{E}$ of irrigation development and management, which are crucial factors for AWD if it were to be adopted and administered system wide. Several adoption studies provide a good understanding of the constraints and opportunities for scaling AWD. However, these experiences were studied in field trials where farmers were pre-selected based on the favorability of the irrigation infrastructure and their willingness to try AWD. Using AWD is not possible in irrigation systems that do not have flow control structures (Delos Reyes, 2017). Moreover, the major problem of declining infrastructure quality, despite investments and rehabilitation efforts, is a significant uncertainty in terms of AWD's widespread use (Le Loan, 2020; Totin et al., 2020).

These findings suggest great uncertainties surrounding AWD's compatibility with widespread adoption in largescale irrigation systems unless the entire institutional and irrigation infrastructure ecosystem is considered and enhanced (Shilomboleni and De Plaen, 2019; Schut et al., 2020). These constraints have yet to be adequately addressed in recent scaling efforts, which are still dominated by technology transferoriented approaches.

\section{Trade-Off and Cross-Scale Issues}

What makes taking AWD to scale in large irrigation systems more challenging is the different cross-scale issues and tradeoffs that arise. Since water saving is tied to how water is reallocated, collective participation in adopting AWD in large systems involves a wider range of stakeholders and resource use systems.

Figures 4A-F show a series of graphs depicting the relationships and trade-offs of AWD adoption and their impact on different variables or outcomes. An increase in AWD adoption area generally results in increased savings in the irrigation amount (Figure 4A), which can be used to maximize the irrigated areas (Figure 4B). These irrigation benefits positively influence income and total productivity. Influences on income have more direct effect in pump irrigated than canal systems. Farmers relying in pump-based irrigation can save almost half of its fuel costs when they properly apply AWD. Figure 4C illustrates the trend of reduction in fuel consumptions for pumping water as the AWD adoption area increases.

On the other hand, AWD can increase weed density (Figure 4D) if farming practices are not coupled with appropriate weed management interventions (Brim-DeForest et al., 2017; Samoy-Pascual et al., 2020). Some studies done in Nepal reported that AWD restricts the proliferation of weeds due to its soil contraction effects (Howell et al., 2015). While we describe the generic agronomic responses of AWD, these trends may vary with diverse agro-environment. Thus, there is a non-linear relationship between AWD and yield, water productivity and income. There are soil type and crop management factors that also contribute to yield performance, e.g., variety, nutrient, weeds, and pest management (Lampayan et al., 2009; TirolPadre et al., 2018). In terms of mitigation benefits, the AWD results in significant reductions in methane emission (Figure 4E). However, the degree of reduction decreases with an increase in the area under AWD. Many plots within the rice landscape remain flooded when other plots might be dried to the extent of scheduling irrigation based on AWD. This connotes the spatial variability effect on gains in methane reduction. At the same time, researchers 


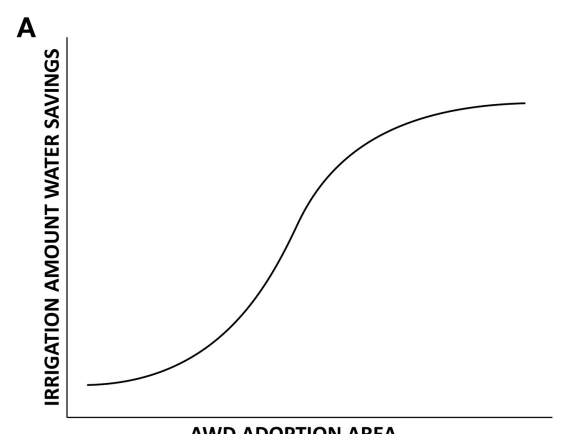

C

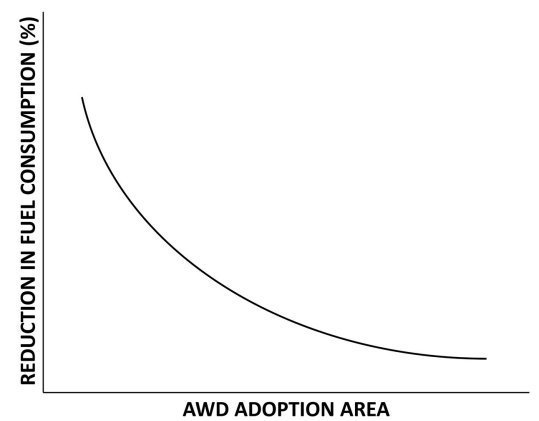

E

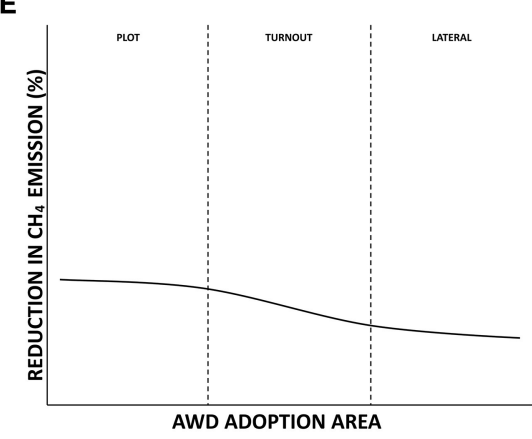

B
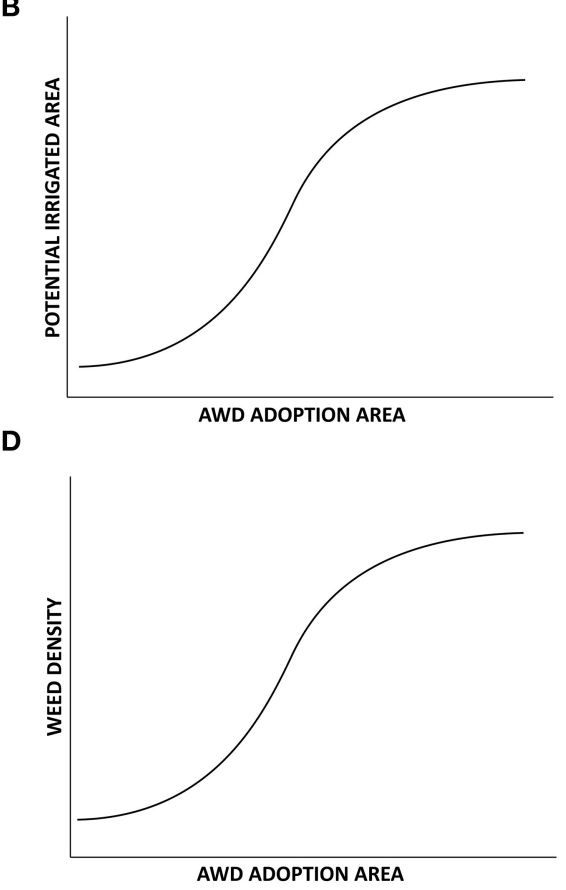

F

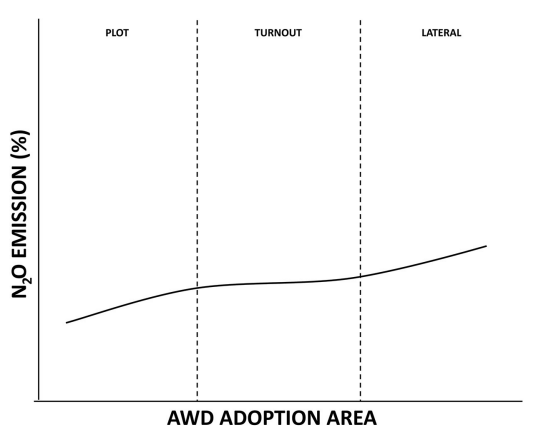

FIGURE 4 | Synergies and trade-offs in AWD adoption by (A) irrigation amount savings, (B) potential irrigated area, (C) reduction in fuel consumption, (D) weed density, (E) reduction in methane emission, and (F) nitrous oxide emission. Graphs represents the generic trend and the responses may vary with diverse agro-environment (Sources: Authors).

found that AWD's mitigating effect on methane can be off-set by nitrous oxide increases (Sibayan et al., 2018) (Figure 4F). However, this results in no significant difference in the total global warming potential between AWD and continuous flooding.

At the irrigation community level, the decision to participate in the collective adoption of AWD is a trade-off in itself. The adoption of technology by upstream farmers means that they take risks or forego a higher probability of achieving better productivity by allowing downstream farmers to benefit from more irrigation. This is why participation and communitybased engagement are crucial for AWD to benefit farmers. However, results can be exponential. Achieving more equitable water supply among the farmers on the upstream-downstream continuum of canal irrigations is the most practical social benefit of successful AWD adoption. It has been shown to provide downstream farmers with yields that are comparable to farmers higher in the toposequence (Valdivia et al., 2016). Through more reliable water and the potential for improved irrigation coverage, successful AWD adoption has been observed to reduce resource conflicts and stimulate trust among farmers (Sibayan et al., 2010; Rejesus et al., 2014; Palis et al., 2017). The presence of an intense collective action to adopt AWD was a critical mechanism that reflected successful pilot and scaling initiatives in both irrigation systems (Palis et al., 2004, 2017; Lampayan et al., 2009; Regalado et al., 2018).

At the systems level, the issue of siltation, primarily caused by rapid degradation of watersheds located at the upstream end in national systems, is significant. Poor watershed conditions increase the risk of erosion and river siltation, reducing the storage capacities of dams and canals and resulting in decreased 
availability and reliability of irrigation water, especially for downstream farmers. Addressing this challenge has been difficult due to governance issues. The management and rehabilitation of watersheds are largely within the purview of the DENR and local governments and the planning and implementation of these efforts are often not coordinated with the NIA (Clemente et al., 2020). In a few reservoir-based gravity systems, fishers were some of the non-farm stakeholders affected by AWD adoption (Rejesus et al., 2017). Fish cage operators, whose operations are on lakes that serve as irrigation system reservoirs are highly dependent on lake water levels for their livelihood. They stand to benefit from improved conservation through AWD application, which minimizes the chance of fish kills triggered by low water levels. Alternatively, fish pond operators located in the upper and middle portion of the irrigation system are inversely affected by limited irrigation use, as they continuously need water to fill their ponds to avoid fish mortality. Scaling AWD irrigation system-wide must consider and balance its effects on fisherfolk to prevent negative consequences.

Alternate wetting and drying's success in enabling carbon financing through the CDM failed to flourish as a result of several techno-economic and institutional bottlenecks that deterred its scalability (Siopongco and Wassmann, 2013). First, there are high transaction costs and capacity requirements for farmers venturing into the mechanism, such as accessing the institutional mechanism, monitoring, reporting, and verifying and claiming payments. These may only be viable through a collective organization of farmers or a cooperative at the landscape level in order to take advantage of economies of scale to reduce transaction costs and institutional mechanisms for verification and access to financing (Siopongco and Wassmann, 2013). This also requires farmers to learn new knowledge and capacities to access carbon finance. Second, as carbon prices could fall below USD 1 per ton of $\mathrm{CO}_{2}$ equivalent, the potential economic returns of the CDM for farmers may not be significant enough to incentivize farmers (Siopongco and Wassmann, 2013). Third, while AWD can drastically reduce irrigation water use and the GHG emissions of farmers, in most cases, the water saved would be used to expand the size of the area irrigated for rice or new crops in future seasons. This means reduced emissions could be off-set by emissions created through newly irrigated land. Ironically, if the water saved is channeled to other sectors, such as urban use, it could be certified as an emission reduction due to a net reduction in global warming potential within the agriculture sector (Wassmann, 2010). This displays the need to think about the various tradeoffs of AWD and its potential as an entry point for water-energynexus work.

Lastly, there is potential for system-level benefits of AWD adoption, but it is not yet clear whether these have already been attained because AWD has yet to be implemented system wide in an NIS. To date, only one study attempted to rigorously evaluate AWD's effect on sub-system levels (Rejesus et al., 2017). It is hypothesized that implementing AWD at the NIS level would allow savings from water efficiency gains to be redirected to other sectors such as power generation. Case studies in UPRIIS and RIIS, which are also located on river basins and watersheds, revealed that water savings in irrigation do not significantly benefit the power sector for two reasons (Rejesus et al., 2017). First, the water volume that flows in the irrigation canals is also the water used for power generation. Second, the power companies tap water by accessing it at the source, the dam and lake. These water bodies are not affected by water efficiency gains from AWD adoption, which happen further downstream.

\section{Alternate Wetting and Drying Potential and Challenges in Global Context}

Many studies conducted in various countries have shown that AWD can reduce both GHG emissions and irrigation water use. A literature search conducted on the Web of Science for articles published from 1975 to 2021 with the keywords "alternate wetting and drying" and "rice" in the title generated at least 100 articles based on work done mostly in Asia. However, using other common terms like control irrigation, intermittent irrigation, and so on, may generate more than 1,000 published articles. Most of these publications focus on plant response to water deficit in terms of genetic, physiological, and agronomic characteristics and GHG emission. The meta-analysis done by Carrijo et al. (2017) using 56 such studies indicated mild yield penalty (5\%) to no effect on yield and a potential irrigation water savings of $23 \%$. However, there are very few studies that confirm the effects of continued use (or expansion of coverage area). Lampayan et al. (2015) reviewed the adoption and economics of AWD in the Philippines, Bangladesh, and Vietnam and concluded that the technique had a high rate of return, with a benefit-cost ratio of $7: 1$. Despite this, there have been no published reports on large-scale adoption of AWD in these countries. Though many studies have indicated great potential for AWD under smallscale irrigation systems, Pandey et al. (2020) argued that the lack of economic incentives to save water has been a major constraint for large-scale adoption in countries like Bangladesh, where groundwater is used for irrigation in $79 \%$ of the total irrigated area. The meta-analysis done by Yagi et al. (2020) based on 31 region-specific studies from five South East Asian countries indicated a potential of $35 \%$ reduction of methane emission with AWD. Like Philippines, many Asian countries including Vietnam, Bangladesh, etc., have considered AWD as the priority mitigation option as part its intended NDC to the UNFCCC (Amjath-Babu et al., 2019; Escobar Carbonari et al., 2019).

The analysis and argument made in this study of the Philippine experience applies to most Asian countries where irrigation access is not directly controlled by farmers. The hierarchy of water governance for surface irrigation is similar in most of the Asian countries. In general, irrigation water is either free or water pricing is based on per unit area irrigated, not on the amount of water used. Most smallholder farmers in Asia have fragmented and scattered land holdings, and the plots located within the command area of the sluice gate or pump generally belong to a number of farmers. It is not possible for farmers to apply irrigation based on the drying pattern of each plot. One of the pre-requisite for the adoption of 
water-saving technologies is an efficient irrigation infrastructure which can promote trust among farmers that they will be able to access the right volume of water at the right time. The benefits of AWD will not be realized in absence of assured irrigation scheduling.

\section{CONCLUSIONS AND RECOMMENDATIONS}

Through the lens of innovation uncertainty, this review analyzes how scaling interventions have dealt with knowledge uncertainties surrounding the adoption and benefits of AWD in various irrigation systems, how trade-offs occur across agroecological systems and governance scales, and how these interactions unraveled cross-scale and cross-level issues that ultimately mitigate the resulting outcomes and impacts. The results show that AWD scaling efforts underwent iterative cycles of technological adaptation, promotion, and scaling. This trajectory is characterized by interdependent mechanisms including (i) multi-stakeholder innovation platforms, (ii) participatory technology adaptation and transfer, (iii) capacity building for research and dissemination, and (iv) evidence generation and communication.

Alternate wetting and drying's early phases (2000-2010) involved a synergistic deployment of a multi-stakeholder platform and participatory technology testing, adaptation, and transfer. These mechanisms provided vertical and horizontal linkages that facilitated communication of evidence and institutional uptake by the Philippine Department of Agriculture and various stakeholders. From 2011 to 2020, the country adopted new scaling pathways, including an institutional mechanism for accessing carbon credit and nationwide participatory demonstrations and trials for disseminating AWD. The carbon credit mechanisms did not flourish due to high transaction costs and trade-offs that occurred across the scale. The wide-scale participatory demonstration was also complemented by a policy issuance aligning irrigation scheduling of canal-based irrigation systems with the AWD schedule. In the later stage, learning from AWD's scaling experience culminated in the development of an IoT-powered decision support tool that provides irrigation advisory service to farmers and irrigation managers, making it easier to adopt AWD, efficiently manage water demand and delivery, and ultimately, sustainably manage water resources. This technology is being benchmarked for applicability in different irrigation contexts.

From the two decades of experience scaling this technology, several constraints to scaling AWD were rooted in the heterogeneity of irrigation contexts that were not anticipated in scaling strategies and the trade-offs that occur when AWD adoption and management reach cross-level and cross-scale. Alternate wetting and drying was found to be successful in small-scale pump-based irrigation systems. However, thus far, the scaling experience with large gravitybased systems has been mostly unsuccessful. The study reveals that several factors influence the scalability of AWD. These are economic incentives, institutional enforcement, excludability of access to unintended users, and quality of irrigation infrastructure. Conditions on these factors were more scale-fit in small-scale pump-based irrigations. However, scaling AWD in large gravity-based irrigation systems is comparably more complex and confronts challenges underpinned by scale mismatches. These constraints cut across institutional enforcement, policy regimes and incentives, management and regulation, and the trade-off of benefit streams across livelihood and spatial scales. Given that most irrigated rice-growing areas are in gravity-based irrigation systems, this explains why AWD's impact is largely abated.

Reflecting on the AWD scaling pathway pursued in the last two decades, the study finds that the dominant focus on product-orientation and technology transfer, and preference for controlled environments has neglected many of the important contextual factors, enabling policy incentives, institutions, and scale sensitivities that mitigated the impacts of AWD. The review's findings point to the importance of rethinking the boundaries and assumptions of scaling theory of change for AWD; this requires proper consideration of the institutional and irrigation systems. There is a scaling gap in understanding and learning the contexts in which AWD could be successful and what it will take to succeed in most gravity-based irrigation systems. Much of this requires exploring these uncertainties; being open to failure, which is expected at least in the short term; and moving beyond scaling strategies driven mainly by technology demonstration of AWD in controlled field conditions.

In order to be more impact-oriented, it is necessary to reframe scaling theory to make it more relevant to farmers' needs, including revenue generation and enhancing resilience to climate change. Addressing the problem of irrigation water must not solely focus on water efficiency, but also on ways of ensuring irrigation to farmers at all times. This shifts the focus from farmer-level water management to consider the entire system of irrigation water provisioning, where the capacity of the irrigation systems to monitor and inform water management decisions properly and ensure availability and flexibility of irrigation water is a critical change mechanism. Thus far, researchers have generated enough evidence on the field-level impact of AWD; it's time to look more broadly at opportunities that will trigger wide-scale adoption at the irrigation system scale to achieve significant irrigation water savings and reduce the carbon footprint.

\section{AUTHOR CONTRIBUTIONS}

YE and SY contributed to conceptualization and methodology. YE conducted formal analysis. All 
authors contributed to the article and approved the submitted version.

\section{FUNDING}

The authors would like to acknowledge the funding received from the International Rice Research Institute Seed Grant, the CGIAR Research Program on Rice and the Swiss Agency for Development and Cooperation (SDC) through the CORIGAP-project entitled Closing Rice Yield Gaps in Asia with Reduced Environmental Footprint (Grant no. 81016734).

\section{REFERENCES}

Allen, J. M., and Sander, B. O. (2019). The Diverse Benefits of Alternate Wetting and Drying (AWD). Available online at: https://hdl.handle.net/10568/101399 (accessed February 18, 2021).

Amjath-Babu, T. S., Aggarwal, P. K., and Vermeulen, S. (2019). Climate action for food security in South Asia? Analyzing the role of agriculture in nationally determined contributions to the Paris agreement. Clim. Policy. 19, 283-298. doi: $10.1080 / 14693062.2018 .1501329$

Andrews, M., Pritchett, L., and Woocock, M. (2017). Building State CapabilityEvidence, Anaysis, Action. New York, NY: Oxford University Press. Available online at: https://library.oapen.org/bitstream/id/bb540dab-9bbb-45ea-8ef14843b24dd432/624551.pdf (accessed June 29, 2020).

Araral, E. (2009). What explains collective action in the commons? Theory and evidence from the Philippines. World Dev. 37, 687-697. doi: 10.1016/j.worlddev.2008.08.002

Arnaoudov, V., Sibayan, E., and Caguioa, R. (2015). Adaptation and Mitigation Initiatives in Philippine Rice Cultivation. United Nations Development Programme. Available online at: http://www.undp.org/content/dam/undp/ library/Environment and Energy/MDG Carbon Facility/AMIA Philippines Final.pdf (accessed February 18, 2021).

Belder, P., Bouman, B. A. M., Cabangon, R., Guoan, L., Quilang, E. J. P., Yuanhua, L., et al. (2004). Effect of water-saving irrigation on rice yield and water use in typical lowland conditions in Asia. Agric. Water Manage. 65, 193-210. doi: 10.1016/j.agwat.2003.09.002

Bouman, B. A. M., Lampayan, R. M., and Tuong, T. P. (2007). Water Management in Irrigated Rice: Coping with Water Scarcity. Manila: International Rice Research Institute. Available online at: https://docs.google.com/file/d/ 0BzpGUgB9NtG5NE9QUndrQWYzdjQ/view (accessed March 15, 2019).

Bouman, B. A. M., and Tuong, T. P. (2001). Field water management to save water and increase its productivity in irrigated lowland rice. Agric. Water Manage. 49, 11-30. doi: 10.1016/S0378-3774(00)00128-1

Breen, S.-P. W., Loring, P. A., and Baulch, H. (2018). When a water problem is more than a water problem: fragmentation, framing, and the case of agricultural wetland drainage. Front. Environ. Sci. 6:129. doi: 10.3389/fenvs.2018.00129

Brim-DeForest, W. B., Al-Khatib, K., Linquist, B. A., and Fischer, A. J. (2017). Weed community dynamics and system productivity in alternative irrigation systems in california rice. Weed Science. 65(1): 177-88. https://doi.org/10.1614/ ws-d-16-00064.1

Briones, R. M., Clemente, R. S., Inocencio, A. B., Luyun, R. A., and Rola, A. C. (2019). "Assessment of the free irrigation service act," in Revitalizing Philippines Irrigation: A systems and Governance Assessment for the 21st Century, ed R. M. Briones (Makati: Philippine Institute for Development Studies). Available online at: https://pidswebs.pids.gov.ph/CDN/PUBLICATIONS/pidsbk2021irrigation book.pdf (accessed January 14, 2021).

Campbell, B. M., Beare, D. J., Bennett, E. M., Hall-Spencer, J. M., Ingram, J. S. I., Jaramillo, F., et al. (2017). Agriculture production as a major driver of the Earth system exceeding planetary boundaries. Ecol. Soc. 22:8. doi: 10.5751/ES-09595-220408

Carrijo, D., Lundy, M., and Linquist, B. (2017). Rice yields and water use under alternate wetting and drying irrigation: a meta-analysis. Field Crops Res. 203, 173-180. doi: 10.1016/j.fcr.2016.12.002
ACKNOWLEDGMENTS

Language editing service provided by Renata Sielecki is duly acknowledged.

\section{SUPPLEMENTARY MATERIAL}

The Supplementary Material for this article can be found online at: https://www.frontiersin.org/articles/10.3389/fsufs. 2021.675818/full\#supplementary-material

Clemente, R. S., Fajardo, A. L., Ballaran, V. G. J., and Ureta, J. L. (2020). "National irrigation systems," in Revitalizing Philippine Irrigation: A Systems and Governance Assessment for the 21st Century, ed R. M. Briones (Makati: Philippine Institute for Development Studies). Available online at: https://pidswebs.pids.gov.ph/CDN/PUBLICATIONS/pidsbk2021irrigation_book.pdf

Cooley, L., and Linn, J. F. (2014). Taking Innovations to Scale: Methods, Applications and Lessons. Washington, DC: Results for Development Institute. Available online at: https://www.usaid.gov/sites/default/files/documents/1865/ v5web_R4D_MSI-BrookingsSynthPaper0914-3.pdf (Accessed February 18, 2021).

Dawe, D., Piedad, M., and Valencia, S. (2009). Institutional, policy and farmer responses to drought: El Niño events and rice in the Philippines. Disasters 33, 291-307. doi: 10.1111/j.1467-7717.2008.01075.x

De Loë, R. C., and Patterson, J. J. (2018). Boundary judgments in water governance: diagnosing internal and external factors that matter in a complex world. Water Resour. Manage. 32, 565-581. doi: 10.1007/s11269-017-1827-y

Delos Reyes, M. L. F. (2017). Modernisation Strategy for National Irrigation Systems in the Phlippines: Balanac and Sta. Maria River Irrigation Systems. London: CRC Press. doi: 10.18174/406141

Dixit, S., Kumar, A., and Woldring, H. (2016). "Water scarcity in rice cultivation: current scenario, possible solutions, and likely impact," in Regional: Development and Dissemination of Climate-Resilient Rice Varieties for Water-Short Areas of South Asia and Southeast Asia. (Mandaluyong: Asian Development Bank (ADB)). Available online at: https://www.adb.org/ sites/default/files/project-document/185360/47163-001-tacr-01.pdf (accessed February 18, 2021).

Eckstein, D., Künzel, V., Schäfer, S., and Winges, M. (2020). Who Suffers Most From Extreme Weather Events? Weather-Related Loss Events in 2018 and 1999 to 2018. Available online at: https://www.germanwatch.org/en/17307 (accessed January 08, 2021).

Escobar Carbonari, D., Grosjean, G., Läderach, P., Nghia, T. D., Sander, B. O., Mckinley, J., et al. (2019). Reviewing Vietnam's nationally determined contribution: a new perspective using the marginal cost of abatement. Front. Sustain. Food Syst. 3:14. doi: 10.3389/fsufs.2019. 00014

FAO (2018). AQUASTAT Main Database. Food and Agriculture Organization of the United Nations (FAO). Available online at: http://www.fao.org/aquastat/en/ databases/maindatabase/ (accessed February 18, 2021).

Glover, D., Sumberg, J., Ton, G., Andersson, J., and Badstue, L. (2019). Rethinking technological change in smallholder agriculture. Outlook Agric. 48, 169-180. doi: $10.1177 / 0030727019864978$

Hall, R., Lizada, J., Dayo, M. H., Abansi, C., David, M., and Rola, A. (2015). To the last drop: the political economy of philippine water policy. Water Policy 17(5): 946-62. https://doi.org/10.2166/wp.2015.150

Hartmann, A., and Linn, J. F. (2008). Scaling Up: A Framework and Lessons for Development Effectiveness From Literature and Practice. Wolfensohn Center for Development Working Paper No. 5. (Online).

Hoffmann, V., Probst, K., and Christinck, A. (2007). Farmers and researchers: how can collaborative advantages be created in participatory research and technology development? Agric. Hum. Values 24, 355-368. doi: 10.1007/s10460-007-9072-2 
Howell, K. R., Pitambar, S., and Dodd, I. C. (2015). Alternate wetting and drying irrigation maintained rice yields despite half the irrigation volume, but is currently unlikely to be adopted by smallholder lowland rice farmers in Nepal. Food Energy Secur. 4, 144-157. doi: 10.1002/fes3.58

Inocencio, A., and Barker, R. (2018). Current challenges in agricultural water resource development and management in the Philippines. DLSU Bus. Econ. Rev. 28, 1-17. https://dlsu-ber.com/2014-2-2/ (accessed October 19, 2019).

Inocencio, A. B., Inocencio, A. D. B., and Briones, R. M. (2020). "Assessing the resurgent irrigation development program of the Philippines: synthesis report," in Revitalizing Philippines Irrigation: A Systems and Governance Assessment for the 21st Century, ed R.M. Briones (Makati: Philippine Institute for Development Studies), 199-224. Available online at: https://pidswebs.pids.gov. ph/CDN/PUBLICATIONS/pidsbk2021-irrigation_book.pdf (accessed January $14,2021)$.

IPCC (2018). "Summary for policymakers, Intergovernmental Panel on Climate, Change (IPCC)," in: Global Warming of $1.5^{\circ} \mathrm{C}$. An IPCC Special Report on the Impacts of Global Warming of $1.5 R^{\circ} \mathrm{C}$ Above Pre-Industrial Levels and Related Global Greenhouse Gas Emission Pathways, in the Context of Strengthening the Global Response to the Threat of Climate Change, Sustainable Development, and Efforts to Eradicate Poverty, eds. V. Masson-Delmotte, P. Zhai, H.O. Pörtner, D. Roberts, J. Skea, P.R. Shukla, A. Pirani, W. Moufouma-Okia, C. Péan, R. Pidcock, S. Connors, J.B.R. Matthews, Y. Chen, X. Zhou, M.I. Gomis, E. Lonnoy, T. Maycock, M. Tignor and T. Waterfield. Available online at: https:// www.ipcc.ch/sr15/chapter/spm/ (accessed January 10, 2021).

IRRI and PhilRice (2020). AutoMonPH - An IoT Based Irrigation Advisory Service. A Comprehensive Solution for Landscape-Scale Sustainable Water Management in Rice. Synthesis Report (v 1.0). Los Baños: International Rice Research Institute (IRRI) and Philippine Rice Research Institute (PhilRice). Available online at: https://drive.google.com/file/d/1wmXCe724XdgDgoHoS0_ 19i6NWybnLoEY/view? usp=sharing (accessed January 22, 2021).

Lampayan, R. M., Bouman, B. A. M., Flor, R. J., and Palis, F. G. (2014). "Developing and disseminating alternate wetting and drying water saving technology in the Philippines," in Mitigating Water-Shortage Challenges in Rice Cultivation: Aerobic and Alternate Wetting and Drying Rice WaterSaving Technologies, ed. A. Kumar (Manila: IRRI, Asian Development Bank,). Available online at: https://www.academia.edu/download/53727357/AWD Phil_Lampayan_et_al.pdf\#page=337 (accessed February 18, 2021).

Lampayan, R. M., Palis, F. G., Flor, R. B., Bouman, B. A. M., Quicho, D., Dios, J. L. D., et al. (2009). "Adoption and dissemination of "Safe Alternate Wetting and Drying" in pump irrigated rice areas in the Philippines," in 60th International Executive Council Meeting and 5th Asian Regional Conference (New Delhi) (accessed February 18, 2021)

Lampayan, R. M., Rejesus, R. M., Singleton, G. R., and Bouman, B. A. M. (2015). Adoption and economics of alternate wetting and drying water management for irrigated lowland rice. Field Crops Res. 170, 95-108. doi: $10.1016 /$ j.fcr.2014.10.013

Le Loan, T. (2020). Alternate wetting and drying technique in paddy production in the Mekong Delta, Vietnam: economic evaluation and adoption determinants. J. Agribus. Dev. Emerg. Econ. 11, 42-59. doi: 10.1108/JADEE-09-2019-0153

Manzano, G., and Prado, S. A. (2014). "Distributional impact of the 2008 rice crisis in the Philippines," in Trade Policies, Household Welfare And Poverty Alleviation, 29. UNCTAD. Available online at: https://unctad.org/en/ PublicationChapters/gds2014d3_02_Philippines_en.pdf

McLean, R., and Gargani, J. (2019). Scaling Impact-Innovatino for the Public Good. London: Routledge.

Menter, H., Kaaria, S., Johnson, N., and Ashby, J. (2004). "Scaling up," in Scaling up and out: Achieving Widespread Impact Through Agricultural Research, $3^{\text {rd }}$ Edn., eds D. Pachico and S. Fujisaka (Cali: International Center for Tropical Agriculture (CIAT)), 9-24. Available online at: https://core.ac.uk/download/ pdf/132664672.pdf (accessed July 16, 2020).

Millar, J., and Connell, J. (2010). Strategies for scaling out impacts from agricultural systems change: the case of forages and livestock production in Laos. Agric. Hum. Values 27, 213-225. doi: 10.1007/s10460-009-9194-9

Moore, M.-L., Riddell, D., and Vocisano, D. (2015). Scaling out, scaling up, scaling deep: strategies of non-profits in advancing systemic social innovation. J. Corp. Citizen. 58, 67+. doi: 10.9774/GLEAF.4700.2015.ju.00009

Mushtaq, S., Dawe, D., Lin, H., and Moya, P. (2006). An assessment of the role of ponds in the adoption of water-saving irrigation practices in the Zhanghe Irrigation System, China. Agric. Water Manage. 83, 100-110. doi: 10.1016/j.agwat.2005.10.004

OCHA (2015). El Niño Snapshot (as of 05 October 2015). United Nations Office for the Coordination of Humanitarian Affairs. Available online at: https://reliefweb.int/report/philippines/philippines-el-ni-o-snapshot-05october-2015 (accessed April 21, 2021).

Palis, F., Lampayan, R., Flor, R., and Sibayan, E. (2017). A multi-stakeholder partnership for the dissemination of alternate wetting and drying water-saving technology for rice farmers in the Philippines. Aims Agric. Food 2, 290-309. doi: 10.3934/agrfood.2017.3.290

Palis, F. G., Bouman, B. A. M., Hossain, M., Lampayan, R. M., Lactaoen, A., Norte, T., et al. (2004). Farmer adoption of controlled irrigation in rice: a case study in Canarem, Victoria, Tarlac. Philip. J. Crop Sci. 29, 3-12. (accessed March 15, 2019).

Pandey, S., Yadav, S., Hellin, J., Balié, J., Bhandari, H., Kumar, A., et al. (2020). Why technologies often fail to scale: policy and market failures behind limited scaling of alternate wetting and drying in rice in Bangladesh. Water 12:1510. doi: $10.3390 /$ w12051510

Pearson, K., Millar, G., Norton, G., and Price, A. (2018). Alternate wetting and drying in Bangladesh: Water-saving farming practice and the socioeconomic barriers to its adoption. Food Energy Secur. 7:e00149. doi: 10.1002/fe s3.149

PSA (2020). CountrySTAT Philippines. Palay: Volume of Production and Area Harvested. Philippine Statistics Authority Statistical Database. Quezon City: Philippine Statistics Authority (PSA)). Available online at: https://psa.gov.ph/ content/selected-statistics-agriculture (accessed February 18, 2021).

Regalado, M. J. C., Sibayan, E., Samoy-Pascual, K., Juliano, L., Ramos, P., Martin, E., et al. (2018). "Accelerating the dissemination of alternate wetting and drying and associated rice production technologies that are resource use efficient," in 15th International Agricultural and Biosystem Engineering Conference and Exhibition (Davao City: Philippine Society of Agricultural and Biosystems Engineers (PSABE)). (accessed February 18, 2021).

Regalado, M. J. C., Yadav, S., Samoy-Pascual, K., De Dios, J. L., Evangelista, G. K., Rafael, M. L., et al. (2019). "Irrigation Advisory Service: a comprehensive solution toward sustainable water management for rice production in the Philippines," in 2019 ASABE Annual International Meeting (St. Joseph, MI: ASABE). Available online at: http://elibrary.asabe.org/abstract.asp?aid= 50429andt $=5$ (accessed February 18, 2021).

Rejesus, R., Palis, F., Rodriguez, D., Lampayan, R., and Bouman, B. (2011). Impact of the alternate wetting and drying (AWD) water-saving irrigation technique: evidence from rice producers in the Philippines. Food Policy 36, 280-288. doi: 10.1016/j.foodpol.2010.11.026

Rejesus, R. M., Martin, A. M., and Gypmantasiri, P. (2014). Enhancing the impact of natural resource management research: lessons from a meta-impact assessment of the Irrigated Rice Research Consortium. Global Food Secur. 3, 41-48. doi: 10.1016/j.gfs.2013.11.001

Rejesus, R. M., Yorobe, J. M. J., Lampayan, R. M., Sibayan, E. B., Sander, B. O., Mendoza, M. L., et al. (2017). Adoption and Impact of Alternate Wetting and Drying (AWD) Water Management for Irrigated Rice Production in the Philippines. A Final Report submitted to the Standing Panel on Impact Assessment (SPIA).

Rola, A. C. (2019). "Strengthening institutional links for irrigation water governance," in: PIDS Policy Notes (Makati: Philippine Institute for Development Studies). Available online at: https://pidswebs.pids.gov.ph/ CDN/PUBLICATIONS/pidspn1909.pdf (accessed February 18, 2021).

Rola, A. C., Olviga, T. R., Faderogao, F. J. F., and Faulmino, C. J. P. (2020). "Irrigation water governance," in Revitalizing Philippine Irrigation: A Systems and Governance Assessment for the 21st Century, ed R. M. Briones (Makati: Philippine Institute for Development Studies), 119-148. Available online at: https://pidswebs.pids.gov.ph/CDN/PUBLICATIONS/pidsbk2021irrigation_book.pdf (accessed January 14, 2021).

Rola, A. C., Pulhin, J. M., and Hall, R. A. (2018). "Water resources in the Philippines: overview and framework of analysis," in Water Policy in the Philippines. Global Issues in Water Policy, eds A. Rola, J. Pulhin, and H. R. Arcala (Cham: Springer), 1-14. doi: 10.1007/978-3-319-70969-7_1

Samoy-Pascual, K., Martin, E. C., and Ariola, C. P. (2020). Effects of water and weed management on the weed density, grain yield, and water productivity of wet-seeded rice. Philippine J. Science. 149(1): 121-31. https://philjournalsci. 
dost.gov.ph/images/pdf/pjs_pdf/vol149no1/effects_of_water_and_weed_ management_on_weed_density_pdf (accessed June 20, 2020).

Sander, B. O., Wassmann, R., Palao, L. K., and Nelson, A. (2017). Climate-based suitability assessment for alternate wetting and drying water management in the Philippines: a novel approach for mapping methane mitigation potential in rice production. Carbon Manage. 8, 331-342. doi: 10.1080/17583004.2017.1362945

Schut, M., Leeuwis, C., and Thiele, G. (2020). Science of scaling: understanding and guiding the scaling of innovation for societal outcomes. Agric. Syst. 184:102908. doi: 10.1016/j.agsy.2020.102908

Seelos, C., and Mair, J. (2017). Innovation and Scaling for Impact: How Effective Social Enterprises Do It? Stanford, CA: Stanford University Press. doi: $10.1515 / 9781503600997$

Shilomboleni, H., and De Plaen, R. (2019). Scaling up research-for-development innovations in food and agricultural systems. Dev. Pract. 29, 723-734. doi: 10.1080/09614524.2019.1590531

Sibayan, E., Samoy-Pascual, K., Grospe, F., Casil, M., Tokida, T., Padre, A., et al. (2018). Effects of alternate wetting and drying technique on greenhouse gas emissions from irrigated rice paddy in Central Luzon, Philippines. Soil Sci. Plant Nutr. 64, 39-46. doi: 10.1080/00380768.2017.1401906

Sibayan, E. B., De Dios, J. L., and Lampayan, R. M. (2010). "Outscaling AWD in a public- managed reservoir-type irrigation system: a case study," in Research to Impact: Case Studies for Natural Resource Management for Irrigated Rice in Asia, eds. F. G. Palis, G. R. Singleton, M. C. Casimero, and B. Hardy (Los Baños: International Rice Research Institute), 135-150.

Siopongco, J. D. L. C., and Wassmann, R. (2013). Alternate wetting and drying in Philippine rice production: feasibility study for a clean development mechanism. IRRI Tech. Bull. 2013:287646. doi: 10.22004/ag.econ.287646

Sumberg, J. (2016). Opinion: the effects of technology adoption on food security: linking methods, concepts and data. Food Secur. 8, 1037-1038. doi: $10.1007 /$ s12571-016-0626-2

Sutton, W. R., Srivastava, J. P., Rosegrant, M., Valmonte-Santos, R., and Ashwill, M. (2019). Striking a Balance: Managing El Niño and La Niña in Philippines' Agriculture. Washington, DC World Bank. Available online at: https:// reliefweb.int/sites/reliefweb.int/files/resources/Striking-a-Balance-ManagingEl-Ni no-and-La-Ni na-in-Philippines-Agriculture.pdf (accessed April 21, 2021).

Tirol-Padre, A., Minamikawa, K., Tokida, T., Wassmann, R., and Yagi, K. (2018). Site-specific feasibility of alternate wetting and drying as a greenhouse gas mitigation option in irrigated rice fields in Southeast Asia: a synthesis. Soil Sci. Plant Nutr. 64, 2-13. doi: 10.1080/00380768.2017.1409602

Totin, E., Van Mierlo, B., and Klerkx, L. (2020). Scaling practices within agricultural innovation platforms: between pushing and pulling. Agric. Syst. 179:102764. doi: 10.1016/j.agsy.2019.102764

Tubiello, F. N., Salvatore, M., Cóndor Golec, R. D., Ferrara, A., Rossi, S., Biancalani, R., et al. (2014). Agriculture, Forestry and Other Land Use Emissions by Sources and Removals by Sinks, 1990 - 2011 Analysis. ESS Working Paper No. 2. FAO Statistical Division. Available online at: http://www.fao.org/docrep/019/i3671e/ i3671e.pdf (accessed February 18, 2021).
USAID (2015). Building Low Emission Alternatives to Develop Economic Resilience and Sustainability Project (B-Leaders): Philippines Mitigation Cost-Benefit Analysis. Integrated report. Available online at: https://climate.gov.ph/files/ 01Feb2016_CBA-Study_0_INTEGRATED.pdf (accessed December 17, 2020).

Valdivia, C. M. D., Sumalde, Z. M., Palis, F. G., Lampayan, R., Umali, C., and Singleton, G. R. (2016). Effects of alternate wetting and drying on rice farming in Bohol, Philippines. Philip. J. Crop Sci. 41, 50-56. (accessed March 16, 2019).

Wassmann, R. (2010). "Implementing the clean development mechanism in the land use sector: status and prospects. Climate change: 'no regret' options for adaptation and mitigation and their potential uptake," in IRRI Limited Proceedings No. 16. Available online at: http://www.fao.org/fileadmin/ templates/agphome/documents/IRRI_website/Irri_workshop/LP_16.pdf (accessed Septmeber 17, 2020).

Wassmann, R., Pasco, R., Zerrudo, J., Ngo, D. M., Vo, T. B. T., and Sander, B. O. (2019). Introducing a new tool for greenhouse gas calculation tailored for cropland: rationale, operational framework and potential application. Carbon Manage. 10, 79-92. doi: 10.1080/17583004.2018.1553436

Wigboldus, S. A., and Leeuwis, C. (2013). Towards Responsible Scaling Up and Out In Agricultural Development: An Exploration of Concepts And Principles. Available: https://edepot.wur.nl/306491 (accessed September 11, 2020).

Woltering, L., Fehlenberg, K., Gerard, B., Ubels, J., and Cooley, L. (2019). Scaling from "reaching many" to sustainable systems change at scale: a critical shift in mindset. Agric. Syst. 176:102652. doi: 10.1016/j.agsy.2019.102652

World Bank (2021). The Climate Change Knowledge Portal. World Bank. Available online at: https://climateknowledgeportal.worldbank.org/downloaddata (accessed April 21, 2021).

Yagi, K., Sriphirom, P., Cha-Un, N., Fusuwankaya, K., Chidthaisong, A., Damen, B., et al. (2020). Potential and promisingness of technical options for mitigating greenhouse gas emissions from rice cultivation in Southeast Asian countries. Soil Sci. Plant Nutr. 66, 37-49. doi: 10.1080/00380768.2019.16 83890

Yamaguchi, T., Tuan, L. M., Minamikawa, K., and Yokoyama, S. (2019). Assessment of the relationship between adoption of a knowledge-intensive water-saving technique and irrigation conditions in the Mekong Delta of Vietnam. Agric. Water Manage. 212, 162-171. doi: 10.1016/j.agwat.2018. 08.041

Conflict of Interest: The authors declare that the research was conducted in the absence of any commercial or financial relationships that could be construed as a potential conflict of interest.

Copyright $\odot 2021$ Enriquez, Yadav, Evangelista, Villanueva, Burac and Pede. This is an open-access article distributed under the terms of the Creative Commons Attribution License (CC BY). The use, distribution or reproduction in other forums is permitted, provided the original author(s) and the copyright owner(s) are credited and that the original publication in this journal is cited, in accordance with accepted academic practice. No use, distribution or reproduction is permitted which does not comply with these terms. 